\title{
Analisis Pengaruh Keberagaman Produk, Persepsi Harga, Promosi Penjualan Terhadap Kepuasan Konsumen Hypermartket Pakuwon Supermall Di Surabaya
}

\author{
Rena Febrita Sarie
}

STIE Urip Somoharjo Surabaya

\begin{abstract}
The purpose of this study is to analyze ans examine the impact of the variety of the product, price perception, sales promotion towards customer satisfaction of hypermarket Pakuwon Supermall in Surabaya. This research is a confirmatory research or conclusive research, which highlights the relationship between the research variables and tests the formulated hypotheses. The sampling technique used in this study is a purposive random sampling. This result of the study showed that sales promotion showed significant positive effect towards customer satisfaction Hypermarket Pakuwon Supermall in Surabaya.

Keywords: Variety of the product, Price Perception, Sales Promotion and Customer Satisfaction.
\end{abstract}

\section{PENDAHULUAN}

Konsep pemasaran bertujuan memberikan kepuasan terhadap keinginan dan kebutuhan pembeli / konsumen. Seluruh kegiatan dalam perusahaan yang menganut konsep pemasaran harus diarahkan untuk memenuhi tujuan tersebut. Meskipun orientasi pembeli ini dibatasi oleh tujuan laba dan pertumbuhan tetapi konsep tersebut perlu dilaksanakan. Hal ini dikarenakan dapat meningkatkan penjualan dengan membuat produk barang atau jasa yang mudah penggunaannya, mudah pembeliannya dan mudah pemeliharaannya. Sedangkan menurut Swastha dan Irawan dalam Kasali (2001:24): “Konsep pemasaran adalah suatu falsafah bisnis yang menyatakan bahwa pemuasan kebutuhan konsumen merupakan syarat ekonomi dan sosial bagi kelangsungan hidup perusahaan”.

Corresponding Author:

Email : rena.febritasarie@gmail.com 
Semakin berkembangnya dunia usaha dan semakin ketatnya persaingan, perusahaan dituntut untuk mampu menciptakan strategi yang tepat dan selalu berorientasi pada selera konsumen tanpa mengabaikan tujuan perusahaan. Tercapainya tujuan tersebut bukanlah suatu kebetulan melainkan suatu pemikiran yang matang dan teliti oleh mereka yang bertanggung jawab atas suatu aktivitas pembelian suatu produk..

Industry retail mencapai perkembangan yang sangat pesat di Indonesia. Hal ini sesuai dengan kecenderungan perekonomian global dimana industri retail semakin diperhitungkan. Menurut Berman dan Evans (2001:301), ada beberapa hal yang membuat industri retail penting untuk dipelajari, yaitu:

(1). Implikasi retailing dalam perekonomian global. Penjualan retail dan daya serap tenaga kerjanya menjadi kunci dalam perekonomian global. (2). Fungsi retail dalam rantai distribusi, retail berfungsi menjadi penghubung antara final consumer dengan manufacturer dan wholesaler. (3). Hubungan antara retailer dan supplier yang memiliki cara pandang yang berbeda. Beberapa masalah yang perlu diperhatikan dalam pola hubungan retailer dan supplier antara lain: control terhadap rantai distribusi, alokasi profit, jumlah retailer pesaing, lokasi, display dan masalah komunikasi melalui promosi dan hubungan masyarakat, sehingga sebuah usaha retail, secara efektif harus memperhatikan keberadaan perilaku konsumen yang menjadi target market mereka.

Bisnis pasar modern sudah cukup lama memasuki industri retail indonesia dan dengan cepat memperluas wilayahnya sampai keplosok daerah, keberadaan mereka banyak menimbulkan pendapat pro-kontra.bagi sebagian konsumen pasar modern. Keberadaan hypermarket, supermarket, dan mini market, memang memberikan alternatif belanja yang menarik. Selain menawarkan kenyamanan dan keberagaman produk. Harga yang mereka tawarkan juga cukup bersaing bahkan lebih murah dibanding pasar tradisional. Sebaliknya keadaan semacam ini jelas membuat risau para retail kecil. Banyak dari retail mendapat imbas dari kehadiran pasar modern seperti hypermarket dengan turunnya pendapatan mereka secara signifikan 
Salah satu unsur kunci dalam persaingan diantara bisnis eceran adalah keragaman produk yang disediakan oleh pengecer. Oleh karena itu pengecer harus membuat keputusan yang tepat mengenai keragaman produk yang dijual. Adanya macam - macam produk dalam arti produk yang lengkap mulai dari merk,ukuran, kualitas.dan ketersediaan porduk .maka akan memudahkan konsumen dalam memilih dan membeli berbagai macam produk sesuai dengan keinginan mereka.

Hypermart Pakuwon Supermall Surabaya adalah salah satu Mall terbesar di Surabaya Barat. Konsep Mall modern dengan retailnya Hypermart merupakan daya tarik konsumen untuk berbelanja di retail tersebut. Keberagaman produk yang ditawarkan oleh Hypermart mulai dari banyaknya merk, segala macam ukuran produk mulai dari yang kecil sampai besar, dan kualitas produk yang baik menjadi hal yang penting bagi konsumen untuk menjadi loyal terhadap Hypermart Pakuwon SuperMall Surabaya.

Selain keragaman produk, Persepsi harga juga merupakan faktor penting yang di perhatikan oleh perusahaan retail. Harga adalah jumlah uang di timbang yang di butuhkan memperoleh beberapa kombinasi sebuah produk dan keragaman menyertainya ( Kotler and Keller,2012). Sedangkan pesepsi harga adalah suatu proses dari seorang individu dalam menyeleksi, mengorganisasikan, dan menerjemahkan stimulus-stimulus atau informasi yang datang menjadi suatu gambaran yang menyeluruh. Harga dianggap sebagai salah faktor yang menentukan bagi perusahaan, tetapi strategi harga bukanlah merupakan satu satunya cara untuk mengatasi berbagai persoalan dalam perusahaan. namun setiap perusahaan hendaknya mempertimbangkan secara matang setiap keputusan dalam masalah harga. Salah satu cara yang di lakukan perusahaan dalam mencapai loyalitas pelanggan dengan memberikan harga yang sesuai kepaada pelanggan. Murah atau mahalnya harga suatu produk sangat relatif sifatnya. Oleh karena itu. perlu dibandingkan terlebih dahulu dengan harga produk serupa yang diproduksi atau dijual oleh perusahan lain. Harga yang terjangkau oleh konsumen, harga yang bersaing dan kesesuaian harga dengan kualitas produk sangat menjadi perhatian bagi Hypermart dalam rangka menarik konsumen untuk menjadi loyal berbelanja di Hypermart Pakuwon Supermall Surabaya. 
Menurut Kotler dan Keller (2009). Promosi dapat di kelompokkan menjadi 4 macam, yaitu: penjualan pribadi (personal selling), periklanan (advertising). Publisitas dan promosi penjualan (sales promotion). Dengan tersedianya promosi beranekaragam bukan berarti kesempatan bagi perusahaan untuk begitu saja memilih tanpa pertimbangan yang matang. Semakin beranekaragam media promosi yang di pakai justru semakin banyak faktor yang perlu di jadikan bahan pertimbangan perusahaan sebelum melakukan kegiatan promosi.

Sales promotion perusahaan menggunakan alat promosi penjualan kupon, kontes, hadiah, dan sejenisnya - untuk menarik tanggapan yang lebih kuat dan lebih cepat dari pembeli, promosi penjualan dapat di gunakan efek jangka pendek seperti menyoroti tawaran produk, promosi penjualan mendapat perhatian dan mungkin mengarahkan ke produk tersbeut, Kotler dan Keller (2009:299).

Hypermarket Pakuwon Supermall Surabaya menggunakan promosi penjualan yaitu dengan memberikan diskon, hadiah, voucher setiap minggu. Konsumen merasa puas dan loyal dengan yang di lakukan hypermarket selain keberagaman produk, harga yang bersaing.

Kepuasan konsumen adalah tingkat perasaan seseorang setelah membandingkan kinerja ( hasil) yang dirasakan, dibandingkan dengan harapan. Konsumen mengalami berbagai tingkat kepuasan ketidakpuasan setelah mengalami masaing - masing jasa sesuai dengan jauh mana harapan konsumen terpenuhi atau terlamapui. Hal ini karena kepuasan adalah keadaan emosional. Reaksi pasca -pembelian konsumen dapat berupa kemarahan, ketidak puasan, kejengkelan, metrlitas, kegembiraan, atau kesenangan. Konsumen yang marah atau tidak puas akan menimbulkan masalah dapat berpindah keperusahaan lain dan menyebarkan kita negatif dari mulut ke mulut. Puas tidaknya konsumen diketahui setelah melakukan pembelian. Tergantung pada kinerja ( hasil) tawaran dalam dalam pemenuhan harapan pembeli. Jika kinerja berada di bawah harapan. Konsumen tidak puas, jika kinerja memenuhi harapan, konsumen puas, jika kinerja melebihi harapan, konsumen amat puas atau senang. Kotler dan Keller (2009). 
Dalam rangka membentuk Kepuasan konsumen Hypermarket harus mengelola lebih baik lagi bisnis ecerannya agar hypermarket dapat memenuhi tuntutan konsumen yang mudah berubah sebagai akibat banyaknya kegiatan kegiatan promosi yang di lakukan oleh para pesaingya. Untuk itu Hypermarket perlu melakukan strategi khusus yaitu pertama dengan memenuhi bisnis ecerannya dengan beragam variasi produk sehingga kelengkapan produk di Hypermart semakin baik dan konsumen tidak perlu belanja ke retail yang lain, kedua menetapkan harga yang selalu murah dan yang ketiga selalu memberikan promosi penjualan yang menarik sehingga kepuasan konsumen dalam berbelanja di hypermart dapat tercapai.

Berdasarkan uraian latar belakang di atas, maka penulis tertarik mengambil judul: “Ananlisis Pengaruh, Keberagaman Produk, Persepsi Harga, Promosi Penjualan Terhadap Kepuasan Konsumen Hypermarket Pakuwon Supermall Di Surabaya".

\section{Tujuan penelitian}

Tujuan penelitian yang hendak di capai adalah:

1. Apakah variabel Keberagaman produk. Persepsi harga dan Pomosi Penjualan berpengaruh secara simultan terhadap Kepuasan konsumen Hypermarket Pakuwon Supermall di Surabya?

2. Manakah dari variable-variabel tersebut, secara parsial dominan memberikan pengaruh terhadap Kepuasan konsumen Hypermaket Pakuwon Supermall di Surabaya?

\section{TINJAUAN PUSTAKA}

\section{Faktor yang Mempengaruhi Efektivitas Pasar}

Dalam menentukan tingkat kepuasan konsumen, terdapat ada 3 (tiga) faktor utama yang harus di perhatikan oleh perusahaan yaitu:

Keberagaman Produk

Keberagaman produk merupakan sekumpulan seluruh produk dan barang yang di tawarkan penjual tertentu kepada konsumen. ( Kotler, 2009) 


\section{Persepsi Harga}

Persepsi harga merupakan kecendrungan konsumen untuk menggunakan dalam memberi penilaian tentang kesesuaian manfaat produk. Penilaian terhadap harga pada suatu manfaat produk di katakan mahal,murah atau sedang yang di persepsikan oleh konsumen.

Pernyataan ini bertujuan untuk mengetahui persepsi harga tersebut. (Kotler dan Keller .2012)

\section{Promosi Penjualan}

Perusahaan menggunakan alat promosi penjualan - kupon, kontes, hadiah, dan sejenisnya - untuk menarik tanggapan yang lebih kuat dan lebih cepat dari pembeli, promosi penjualan dapat di gunakan efek jangka pendek seperti menyoroti tawaran produk, promosi penjualan mendapat perhatian dan mungkin mengarahkan ke produk tersbeut, ( Kotler 2009)

\section{Keterkaitan Promosi Penjualan}

Promosi penjualan adalah sebuah kegiatan yang bersifat ajakan, memberikan nilai tambah atau insentif untuk membeli produk, kepada pengecer, penjual, atau konsumen. Hal ini berarti promosi penjualan berorientasi pada konsumen yang diarahkan pada pengguna akhir sebuah barang dan jasa. Kekuatan-kekuatan utama dari promosi penjualan berorientasi konsumen adalah keseragaman dan fleksibilitasnya.

Keadaan ini mengakibatkan suatu konsumen mempunyai satu motif pembelian, yang dipandang sebagai kebutuhan yang timbul, rangsangan, atau gairah. Motif ini berlaku sebagai kekuatan yang merangsang tingkah laku yang ditujukan untuk memuaskan kebutuhan yang timbul. Intinya promosi penjualan dapat mengakibatkan terjadinya pengambilan keputusan yang salah satunya adalah bersifat emosional.

Intinya promosi penjualan (sales promotion) mempunyai tujuan memotivasi konsumen untuk membeli, artinya adanya perilaku konsumen dalam membeli yang melibatkan emosi bagi si pembelinya. Emosi ini timbul karena 
adanya daya tarik atas sentimen atau gairah tertentu. Kondisi ini timbul karena adanya desakan untuk memenuhi kebutuhan hidup dengan cepat.

Tujuan dari promosi penjualan adalah menciptakan ketertarikan dan mengalihkan perhatian dari harga. Intinya ketertarikan itu akan menimbulkan gairah atau antusiasme pembeli untuk membeli suatu produk dan tetap membeli kepada toko yang bersangkutan. Mengalihkan perhatian dari harga berkaitan dengan adanya perang harga diantaranya variasi harga, promosi kolektor harga, dan membuat perbandingan harga yang tidak langsung. Promosi terhadap nilai yang menciptakan ketertarikan dan mengakibatkan pembelian tidak terencana

Selanjutnya bahwa Tujuan dari promosi penjualan adalah meningkatkan volume penjualan jangka pendek dengan menciptakan tampilan dan aktivitas yang menarik untuk mendorong impulse buying. Tampilan ini menimbulkan suatu kegairahan untuk membeli atau merupakan suatu rangsangan tingkah laku untuk memuaskan kebutuhan hidup.

\section{Kepuasan Konsumen.}

Dalam upaya memenuhi kepuasan konsumen, perusahaan memang dituntut kejeliannya untuk mengetahui pergeseran kebutuhan dan keinginan konsumen yang hampir setiap saat berubah.pembeli akan bergerak setelah membentuk persepsi terhadap nilai penawaran, kepuasan sesudah pembelian tergantung dari kinerja penawaean dibandingkan dengan harapannya. Menurut Kotler dan Keller (2009:51).

Menurut kotler dan Keller. (2009) kepuasan konsumen adalah tingkat perasaan seseorang setelah membandingkan kinerja dan hasil yang dirsakan dibandingkan dengan harapannya. Konsumen dapat mengalami salah saru dari tiga tingkat kepuasan umum yaitu kalau kinerja dibawah harapan, konsumen akan merasa kecewa tetapi jika kinerja sesuai dengan harapan pelanggan akan merasa puas dan apa bila kinerja bisa melebihi dan harapan maka pelanggan akan merasakan sangat puas senang atau gembira.

Kepuasan konsumen label yang digunakan oleh konsumen untuk meringkas satu himpunan aksi atau tindakan yang terlihat, terkait dengan produk 
dan jasa. Kepuasa konsumen merupakan positif konsumen yang berhubungan dengan jasa dan produk.

Kesesuaian yang mengalami ketidak kesesuaian antara harapan dengan kinerja aktual jasa atau produk maka konsumen berada pada diskonfirmasi. Jadi dapat disimpulkan dari beberapa pengertian tersebut menurut para ahli, bahwa kepuasan konsumen adalah tingkat perasaan seseorang ketika menerima produk dan jasa yang ditawarkan serta membandingkan kinerja atas produk atau jasa yang di terima dengan harapan yang dimiliki.

Menurut Kotler \& Keller (2012:150). Yang berarti kepuasan adalah perasaan puas atau kecewa seseorang yang dihasilkan dari perbandingan performa produk atau hasil dengan ekspektasi. Jika performanya kurang dari ekspektasi maka pelanggan akan kecewa dan jika sesuai dengan ekspektasi konsumen akan merasa puas.

Menurut Fandy Tjiptono (2014:353) , kepuasan berasal dari bahasa Latin "Satis" yang berarti cukup baik, memadai dan "Facio" yang berarti melakukan atau membuat. Secara sederhana kepuasan bisa diartikan sebagai upaya pemenuhan sesuatu atau membuat sesuatu memadai.

Enam konsep inti mengenai objek pengukuran kepuasan konsumen :

- Kepuasan pelanggan keseluruhan

- Dimensi kepuasan Konsumen

- Konfirmasi harapan.

- Niat beli ulang.

- $\quad$ Kesediaan untuk merekomendasi.

- Ketidakpuasan Konsumen

Menurut Kotler \& Keller (2012) yang dikutip oleh Fandy ada beberapa metode yang dipergunakan dalam mengukur kepuasan Konsumen, antara lain :

1. Sistem keluhan dan saran

Setiap organisasi jasa yang berorientasi pada Konsumen wajib untuk memberikan kesempatan bagi seluas-luasnya bagi para Konsumen untuk menyampaikan saran, kritik, pendapat dan keluhan mereka. Informasi yang didapatkan dari metode ini dapat menjadi masukan yang berharga 
bagi perusahaan sehingga memungkinkan untuk bereaksi dengan tanggap dan cepat dalam mengatasi masalah yang timbul. Akan tetapi metode ini pasif, sehingga sulit untuk mendapatkan gambaran secara lengkap mengenai kepuasan atau ketidakpuasan Konsumen. Tidak semua Konsumen langsung tidak mau membeli produk atau jasa dari perusahaan tersebut lagi.

\section{Ghost / Mystery Shopping}

Salah satu metode untuk memperoleh gambaran mengenai kepuasan pelanggan adalah dengan mempekerjakan beberapa orang ghost shoppers untuk berperan atau berpura-pura sebagai pelanggan potensial terhadap pembeli produk perusahaan dan produk perusahaan pesaing. Kemudian mereka diminta untuk melaporkan temuan penting mengenai kekuatan dan kelemahan dari produk/jasa perusahaan maupun produk/jasa perusahaan para pesaing. Selain itu, para ghost shoppers juga dapat langsung melakukan observasi cara perusahaan dan pesaingnya penanganan terhadap keluhan yang ada baik oleh perusahaan yang bersangkutan maupun oleh pesaingnya melayani permintaan spesifik pelanggan, menjawab pertanyaan pelanggan, dan menangani setiap masalah dan keluhan pelanggan.

\section{Lost Customer Analysis}

Perusahaan akan menghubungi para pelanggan yang telah berhenti membeli produk atau telah pindah pemasok, agar dapat memahami mengapa pelanggan tersebut berpindah ke tempat lain dan dapat mengambil kebijakan / penyempurnaan selanjutnya. Kesulitan dari meotde ini adalah pada mengidentifikasi dan mengkontak mantan pelanggan yang bersedia memberikan masukan dan evaluasi terhadap kinerja perusahaan.

\section{Survei Kepuasan Konsumen}

Sebagian besar riset kepuasan pelanggan dilakukan dengan menggunakan metode survei baik melalui pos, telepon, email, website, maupun wawancara langsung (McNeal\&Lamb dalam Peterson\&Wilson). Melalui survey perusahaan akan memperoleh tanggapan dan umpan balik secara 
langsung dari pelanggan dan juga memberikan kesan positif terhadap para pelanggannya bahwa perusahaan menaruh perhatian terhadap mereka.

Menurut Fandi Tjiptono (2014). perusahaan yang telah berhasil membentuk fokus pada kepuasan Konsumen memiliki karakteristik sebagai berikut :

- Visi dan Komitmen

- Pensejajaran dengan Konsumen

- Kemauan mengidentifikasi masalah Konsumen

- Memanfaatkan informasi dari Mendekati Konsumen

- Kemampuan, kesanggupan dan pemberdayaan karyawan

- Penyempurnaan produk dan proses terus menerus

Dimensi Kepuasan Pelanggan, hal yang dapat mempengaruhi kepuasan pelanggan dapat dilihat dari ukuran atau dimensi kepuasan pelanggan menurut Kotler\&Keller (2012), yaitu:

- Tetap setia

Konsumen yang terpuaskan cenderung akan menjadi setia atau loyal. Konsumen yang puas terhadap produk yang dikonsumsinya akan mempunyai kecenderungan untuk membeli ulang dari produsen yang sama.

- Membeli produk yang ditawarkan

Keinginan untuk membeli produk atau makanan lain yang ditawarkan karena adanya keinginan untuk mengulang pengalaman yang baik dan menghindari pengalaman yang buruk.

- Merekomendasikan produk

Kepuasan merupakan faktor yang mendorong adanya komunikasi dari mulut ke mulut yang bersifat positif. Hal ini dapat berupa rekomendasi kepada calon konsumen yang lain dan mengatakan hal-hal yang baik mengenai produk dan perusahaan yang menyediakan produk.

- Bersedia membayar lebih 
Konsumen cenderung menggunakan harga sebagai patokan kepuasan, ketika harga lebih tinggi konsumen cenderung berfikir kualitas menjadi lebih tinggi juga.

- Memberi masukan

Walaupun kepuasan sudah tercapai, konsumen selalu menginginkan yang lebih lagi, maka konsumen akan memberi masukan atau saran agar keinginan mereka dapat tercapai.

Untuk dapat memuaskan kebutuhan pelanggan, perusahaan dapat melakukan beberapa tahapan ( Fandi Tjiptono. 2014) :

- Mengetahui kebutuhan dan keinginan pelanggan

- Mengetahui proses pengambilan keputusan dalam membeli produk

- Membangun citra perusahaan

- Membangun kesadaran akan pentingnya kepuasan pelanggan.

\section{METODE PENELITIAN}

\section{Definisi Operasional Variabel}

Definisi operasional adalah definisi yang bersifat memeberikan arti kepada suatu variabel dengan menetapkan kegiatan atau tindakan yang perlu untuk mengukur variabel tersebut. Definisi operasional ini akan memberikan batasan atau ciri-ciri suatu variabel dengan perinci hal-hal yang harus di kerjakan oleh peneliti untuk mengukur variabel tersebut..

Keragaman Produk. (X1) Terdiri dari 3 indikator:

1. Merek tersedia banyak.

2. Ukuran Produk dari yang kecil sampai yang besar.

3. Kualitas produk untuk memenuhi kepuasan konsumen Persepsi harga $\left(\mathrm{X}_{2}\right)$ terdiri dari 3 indikator:

1. Harga bersaing

2. Harga terjangkau

3. Harga sesuai kualitas 
Promosi Penjualan (X3) terdiri dari 3 indikator:

1. Kupon diskon

2. Voucher

3. Promo Hadiah

\section{Pengukuran Variabel}

Pengukuran variabel dengan menggunakan skala liket, Nilai dari jawaban yang di berikan atas kuisioner di bedakan menjadi lima tingkatan yaitu:
a) Sangat setuju 5
b) Setuju 4
c) Ragu-ragu 3
d) Tidak setuju 2
e) Sangat tidak setuju 1

\section{Populasi dan Sampel}

\section{Populasi}

Populasi menurut Sugiono(2014:148) dalam buku statistik untu peneltian menyatakan bahwa: "populasi adalah wilayah generalisasi yang terdiri dari obyek atau subyek yang mempunyai kuantitas dan karakteristik tertentu yang di tetapkan oleh peneliti untuk di pelajari dan kemudian untuk di tarik kesimpulan. Populasi dalam penelitian ini adalah seluruh konsumen yang berbelanja di Hypermarket Pakuwon Supermall Surabaya

\section{Sampel}

Di karenakan jumlah populasi yang sangat besar dan adanaya ketebatasan waktu dan tenaga yang di miliki, maka teknik pengambilan sampel yang di gunakan adalah puposive random sampling, purposive random sampling adalah teknik pengambilan sampel secara acak namun di sertai oleh kriteria-kriteria tertentu (Sugiono, 20014:150) kretria tertentu dimana penulis memberikan kuesioner 50 konsumen yang berbelanja produk di Hypermarket Pakuwon Supermall Surabaya. Kriteria-kriteria tersebut adalah konsumen sering yang berbelanja di Hypermarket Pakuwon Supermall Surabaya. Atau di sebut konsumen reguler yang sering datang dan membeli produk minimal 2 bulan sekali. 


\section{Teknik pengambilan sampel}

Dalam penelitian ini. Teknik sampling yang di gunakan adalah purposive random sampling. Seperti telah di kemukakan bahwa puposive adalah penelitian sampel berdasarkan pertimbangan atau karakteristik tertentu sesuai dengan tujuan penelitian, Sugiono (2014:151)

\section{Jenis data dan sumber data}

\section{Jenis Data}

Jenis data dalam penelitian ini dalah:

1.Data Kualitatif. Yaitu data yang tidak berbentuk angka. Kalimat, skema, dan gambar seperti literature-literature serta teori-teori yang berkaitan dengan peneletian penulis.

2.Data Kuantitatif. Yaitu data yang berbetuk angka - angka atau data Kualitatif yang diangkakan (scoring)

\section{Sumber data}

Sumber data yang di gunakan adalah:

1.Data Primer, yaitu data yang di peroleh langsung dari responden melalui wawancara dan kuesioner di hypermarket Pakuwon Supermall Surabaya.

2.Data Sekunder, yaitu data yang di peroleh dalam bentuk yang sudah jadi, sudah di kumpulkan dan di peroleh pihak lain. Biasanya sudah dalam bentuk publikasi seperti data yang di peroleh dari situasi-situasi internet dan data lainnya yang berhubungan langsung dengan objek yang di teliti.

\section{Teknik Pengumpulan Data}

Data yang terkumpul akan di analisis dengan menggunakan teknik analisis statstisk dengan menggunkan program SPSS, dimana rumus statistik yang di gunakan adalah linear multiple regession ( regresi linear berganda), di mana fungsinya dalah:

$\mathrm{Y}=\mathrm{a}+\mathrm{b} 1 . \mathrm{X} 1+\mathrm{b} 2 \cdot \mathrm{X} 2+\mathrm{b} 3 \cdot \mathrm{X} 3+\ldots+\mathrm{e}$

Fungsi tersebut menerangkan hubungan antara dua variabel bebas (X) dan variabel terikat $(\mathrm{Y})$ dimana: 
$\mathrm{Y}=$ Kepuasan Konsumen

$\mathrm{a}=$ Konstanta

b1 s/d b3 =koefision regresi

$\mathrm{X} 1=$ Keberagaman Produk

X2= Persepsi Harga

X3 = Promosi Penjualan

e = estimate of error dari masing - masing variabel

\section{PEMBAHASAN}

Hasil uji regresi linier berganda tentang kekuatan variabel independen terhadap variabel independen adalah sebagai berikut:

\section{Tabel 4.5}

\section{Hasil Uji Regresi Linier Berganda}

\section{Coefficients $^{\mathrm{a}}$}

\begin{tabular}{|c|c|c|c|c|c|c|}
\hline \multirow{2}{*}{\multicolumn{2}{|c|}{ Model }} & \multicolumn{2}{|c|}{$\begin{array}{c}\text { Unstandardized } \\
\text { Coefficients }\end{array}$} & \multirow{2}{*}{$\begin{array}{c}\text { Standardized } \\
\text { Coefficients }\end{array}$} & \multirow[t]{2}{*}{$\mathrm{t}$} & \multirow[t]{2}{*}{ Sig. } \\
\hline & & B & Std. Error & & & \\
\hline \multirow{5}{*}{1} & (Constant) & 3.763 & 1.495 & & 2.518 & .015 \\
\hline & KeberagamanPro & & & & & \\
\hline & & -.095 & .229 & -.081 & -.416 & .679 \\
\hline & PersepsiHarga & -.016 & .225 & -.015 & -.071 & .944 \\
\hline & SalesPromotion & .821 & .206 & .796 & 3.982 & .000 \\
\hline
\end{tabular}

a. Dependent Variable: total_y Kepuasan Konsumen

Berdasarkan tabel tersebut, maka dapat dibuat suatu persamaan regresi sebagai berikut:

$$
Y=3.763-0.095 X_{1}-0.016 X_{2}+0.821 X_{3} .
$$

persamaan regresi di atas dapat dijelaskan sebagai berikut:

a.Nilai Konstanta (a) sebesar 3.763 menunjukkan bahwa jika nilai $\mathrm{X}_{1}, \mathrm{X}_{2}$, dan $\mathrm{X}_{3}=0 \quad$ maka nilai $\mathrm{Y}=3.763$ artinya ketika nilai variabel 
keberagaman produk, Persepsi Harga, Promosi Penjualan sebesar 0, maka kepuasan konsumen memiliki nilai sebesar 3.763.

b.Koefisien regresi $\mathrm{X}_{1}\left(\mathrm{~b}_{1}\right)$ sebesar -0.095 menunjukkan bahwa apabila skor keberagaman produk naik 1 point. Maka skor kepuasan konsumen akan turun 0.095 .

c.Koefisien regresi $\mathrm{X}_{2}\left(\mathrm{~b}_{2}\right)$ sebesar - 0.016 menunjukkan bahwa apabila persepsi harga naik 1 point, maka skor kepuasan konsumen akan turun sebesar 0.016.

d. Koefisien regresi $\mathrm{X}_{3}\left(\mathrm{~b}_{3}\right)$ sebesar 0.821 menunjukkan adanya pengaruh Promosi penjualan terhadap kepuasan konsumen bahwa apabila sales promotion naik 1 point, maka skor kepuasan konsumen akan naik 0.821

\section{Hasil Uji Determinasi $\left(\mathbf{R}^{2}\right)$}

Menurut Ghazali, Imam (2009:87) untuk menentukan seberapa besar variabel independen dapat menjelaskan variabel dependen, maka perlu diketahui nilai koefisien determinasi

(R Square). Adapun hasil uji determinasinya adalah sebagai berikut:

Tabel 4.6

\section{Hasil Uji Determinasi (Adjusted R ${ }^{2}$ )}

Model Summary

\begin{tabular}{|l|r|r|r|r|}
\hline $\begin{array}{l}\text { Mode } \\
1\end{array}$ & \multicolumn{1}{|c|}{$\mathrm{R}$} & $\mathrm{R}$ Square & $\begin{array}{c}\text { Adjusted R } \\
\text { Square }\end{array}$ & $\begin{array}{r}\text { Std. Error of } \\
\text { the Estimate }\end{array}$ \\
\hline 1 & $.721^{\mathrm{a}}$ & .519 & .488 & 1.199 \\
\hline
\end{tabular}

a. Predictors: (Constant), kebergaman produk, Persepsi

Harga, Sales promotion

b. Dependent Variabel: kepuasan konsumen

berdasarkan tabel di atas diketahui nilai $\boldsymbol{R}$ Square sebesar 0.519 ini menunjukkan bahwa dengan menggunakan model regresi didapatkan variabel independen yaitu keberagaman produk. persepsi harga dan Promosi Penjualan memiliki pengaruh terhadap variabel Kepuasan Konsumen. Sedangkan sisanya di jelaskan dengan faktor atau variabel lain yang tidak diketahui dan tidak termasuk dalam analisis regresi ini seperti distribusi, Promosi dan lain -lain. 


\section{Uji Hipotesis}

\section{Hasil Uji F}

Pengujian ini bertujuan untuk membuktikan apakah variab independen (X) secara simultan (bersama - sama) mempunyai pengaruh terhadap variabel dependen ( Y) (Ghazali.2009:88). Apabila $\mathrm{F}_{\text {hitng }}>\mathrm{F}_{\text {tabel }}$ maka $\mathrm{H}_{0}$ ditolak dan $\mathrm{H} 1$ diterima, yang artinya variabel indenpenden mempunyai pengaruh yang signifikan terhadap variabel dependen. Selain itu bila signifikansinya adalah lebih kecil dar $\mathbf{a = 0 . 0 5}$ maka arrtinya $\mathbf{H}_{\mathbf{0}}$ ditolak dan $\mathbf{H}_{\mathbf{1}}$ diterima.

Tabel 4.7

\section{Hasil Uji Statistik F (Simultan)}

ANOVA ${ }^{\mathrm{a}}$

\begin{tabular}{|c|r|r|r|r|r|}
\hline \multicolumn{1}{|l|}{ Model } & \multicolumn{1}{c|}{$\begin{array}{c}\text { Sum of } \\
\text { Squares }\end{array}$} & \multicolumn{1}{c|}{ Df } & \multicolumn{1}{c|}{$\begin{array}{c}\text { Mean } \\
\text { Square }\end{array}$} & F & Sig. \\
\hline Regression & 71.431 & 3 & 23.810 & 16.573 & $.000^{\mathrm{b}}$ \\
Residual & 66.089 & 46 & 1.437 & & \\
Total & 137.520 & 49 & & & \\
\hline
\end{tabular}

a. Dependent Variable: total_Kepuasan Konsumen

b. Predictors: (Constant), Keberagaman Produk.Persepsi Harga.Sales promotion

Untuk mengujji signifikan varibel indenpen apakah secara simultan berpengaruh terhadap variabel dependent dapat dibuktikan dengan uji $\mathrm{F}$ sebagai berikut:

a.Menentukan besar pengaruh.

Untuk mengetahui ada tidaknya pengaruh yang signifikan secara simultan keberagaman produk, persepsi harga. sales promotion terhadap kepuasan konsumen maka di lakukan pengujian hipotesis sebagai berikut:

$\mathrm{H}_{0}: \mathrm{b} 1=\mathrm{b} 2=\mathrm{b} 3=0$; keberagaman produk.persepsi harga dan sales promotion secara simultan tidak pengaruh terhadap kepuasan konsumen.

$\mathrm{H}_{1} ; \mathrm{b} 1 \neq \mathrm{b} 2 \neq \mathrm{b} 2 \neq 0$; keberagaman produk.persepsi harga dan sales promotion secara simultan pengaruh terhadap kepuasan konsumen. 


\section{b.Menghitung $F_{\text {hitung }}$}

Hasil uji $\mathrm{F}$ dapat dilhat pada tabel di atasa ini $\mathrm{F}_{\text {hiutng }}$ diperoleh sebesar $16.573>$ $\mathrm{F}_{\text {tabel }}$ sebesar 4.458 dengan tingkat signifikansi 0.000 karena tingkat Signifikansi lebih kecil dari 0.05 maka $\mathrm{H}_{1}$ diterima, sehingga dapat disimpulkan bahwa keberagman produk, persepsi harga dan sales promotion simultan (bersama sama) berpengaruh signifikan terhadap kepuasan konsumen.

c. Kriteria Pengujian

Apabila $\mathrm{F}_{\text {hitung }}>\mathrm{H}_{\text {tabel }}$ maka $\mathrm{H}_{0}$ ditolak dan $\mathrm{H}_{1}$ diterima.

Apabila $\mathrm{F}_{\text {hitung }}<\mathrm{H}_{\text {tabel }}$ maka $\mathrm{H}_{0}$ ditolak dan $\mathrm{H}_{1}$ ditolak.

d. Hasil pengujian

Dalam penelitian ini digunakan tingkat kesalahan sebesar 0.05 dengan derajat bebas $(\mathrm{df})=$

$\mathrm{n}-\mathrm{k}-1$ sehingga $\mathrm{F}_{\text {tabel }}$ dengan $\boldsymbol{\alpha}=\mathbf{0 . 0 5} ; 3 ; 46$, sebesar 4.458 .

e. Interpretasi

Nilai $F_{\text {hitumg }}$ sebesar $8.840>\mathrm{f}_{\text {tabel }}$ sebesar 4.458 sehingga $\mathrm{H}_{0}$ ditolak $\mathrm{H}_{1}$ diterima. Arrtinya bahwa seluruh variabel indenpenden yaitu keberagaman produk, persepsi harga, dan penjualan berpengaruh signifikan terhadap variabel dependen yaitu kepuasan konsumen.

\section{Hasil Uji t}

Untuk mengetahui apakah variabel indenpenden secara parsial individual mempunyai pengaruh yang signifikan terhadap variabel dependen. Uji statistik $\mathrm{t}$ pada dasarnya menunjukkan seberapa jauh pengaruh satu variabel individual indenpenden secara individual dalam menerangkan variabel dependen Ghozali, Imam (2009:88). Uji t digunakan nutuk mengetahui apakah pengaruh variabel indenpenden berpengaruh secara parsial terhadap variabel dependen bersifat menentukan signifikan atau tidak. 
Tabel 4.8

Hasil Uji statistik T (Parsial)

Coefficients $^{\mathbf{a}}$

\begin{tabular}{|c|c|c|c|c|c|c|}
\hline \multirow{2}{*}{\multicolumn{2}{|c|}{ Model }} & \multicolumn{2}{|c|}{$\begin{array}{c}\text { Unstandardized } \\
\text { Coefficients }\end{array}$} & \multirow{2}{*}{$\begin{array}{c}\begin{array}{c}\text { Standardized } \\
\text { Coefficients }\end{array} \\
\text { Beta }\end{array}$} & \multirow[t]{2}{*}{$\mathrm{t}$} & \multirow[t]{2}{*}{ Sig. } \\
\hline & & $\mathrm{B}$ & Std. Error & & & \\
\hline \multirow{4}{*}{1} & (Constant) & 3.763 & 1.495 & & 2.518 & .015 \\
\hline & $\begin{array}{l}\text { Keberamanprod } \\
\text { uk }\end{array}$ & -.095 & .229 & -.081 & -.416 & .679 \\
\hline & PersepsiHarga & -.016 & .225 & -.015 & -.071 & .944 \\
\hline & SalesPromotion & .821 & .206 & .796 & 3.982 & .000 \\
\hline
\end{tabular}

a. Dependent Variable: total_Kepuasan Konsumen

Berdasarkan tabel di atas dapat dilihat uji t sebegai berikut:

\section{Uji Variabel Keberagaman Produk Terhadap Kepuasan Konsumen.}

Pengaruh variabel keberagaman produk terhadap kepuasan konsumen menunjukkan nilai koefisien regresi sebesar - 0.095 yang berarti pengaruh variabel keberagaman produk terhadap kepuasan konsumen adalah sebesar 0.095. Dengan membandingkan nilai $t_{\text {hitung }}$ dan nilai $t_{\text {tabel }}$ maka dapat disimpulkan bahwa maka $\mathrm{H}_{0}$ diterima dan $\mathrm{H}_{1}$ ditolak karena nilai $\mathrm{t}_{\text {hitung }}=-0.416>$ nilai $\mathrm{t}_{\text {tabel }}$ sebesar - 2.012. Jika $t_{\text {hitung }}$ sebesar - $0.416>$ nilai $t_{\text {tabel }}$ sebesar - 2.012. hal ini berarti $\mathrm{H}_{0}$ diterima dan $\mathrm{H}_{1}$ ditolak sehingga secara parsial variabel keberagaman produk tidak pengaruh signifikan terhadap kepuasan konsumen.

\section{Uji Variabel Persepsi Harga Terhadap Kepuasan Konsumen}

Pengaruh variabel persepsi harga terhadap kepuasan konsumen menunjukkan nilai koefisien regresi sebesar - 0.016 yang berarti pengaruh variabel persepsi harga terhadap kepuasan konsumen adalah sebesar - 0.016.

Dengan membandingkan nilai $t_{\text {hitung }}$ dan nilai $t_{\text {tabel }}$ maka dapat disimpulkan bahwa maka $\mathrm{H}_{0}$ diterima dan $\mathrm{H}_{1}$ ditolak karena nilai $t_{\text {hitung }}-0.071>$ 
nilai $t_{\text {tabel }}$ sebesar - 2.012. Jika $t_{\text {hitung }}$ sebesar - $0.071>$ nilai $t_{\text {tabel }}$ sebesar - 2.012. hal ini berarti $\mathrm{H}_{0}$ diterima dan $\mathrm{H}_{1}$ ditolak sehingga secara parsial variabel persepsi harga tidak pengaruh signifikan terhadap kepuasan konsumen.

\section{Uji Variabel Promosi Penjualan Terhadap Kepuasan Konsumen.}

Pengaruh variabel Promosi Penjualan terhadap kepuasan konsumen menunjukkan nilai koefisien regresi sebesar 0.821 yang berarti pengaruh variabel promosi penjualan terhadap kepuasan konsumen adalah sebesar 0.821 .

Dengan membandingkan nilai $t_{\text {hitung }}$ dan nilai $t_{\text {tabel }}$ maka dapat disimpulkan bahwa maka $\mathrm{H}_{0}$ diterima dan $\mathrm{H}_{1}$ ditolak karena nilai $\mathrm{t}_{\text {hitung }}=3.982>$ nilai $\mathrm{t}_{\text {tabel }}$ sebesar 2.012. Jika thitung sebesar $3.982>$ nilai tabel sebesar 2.012. hal ini berarti $\mathrm{H}_{0}$ ditolak dan $\mathrm{H}_{1}$ diterima sehingga secara parsial variabel promosi penjualan mempunyai pengaruh signifikan terhadap kepuasan konsumen.

\section{SIMPULAN DAN SARAN}

\section{Simpulan}

Berdasarkan dari penelitian dan pembahasan mengenai analisis berpengaruh keberegaman produk, persepsi harga, dan promosi penjualan terhadapap kepuasan konsumen, maka dapat ditarik beberapa kesimpulan sebagai berikut:

1. Berdasarkan hasil uji regresi linear berganda secara simultan ditemukan bahwa seluruh variabel indenpent ( Keberagaman produk. Persepsi harga. Promosi penjualan) bepergaruh signifikan terhadap Kepuasan Konsumen di Hypermarket Supermall Pakuwon di Surabaya.

2. Hasil regresi linier berganda menunjukkan bahwa nilai $t_{\text {hitung variabel }}$ keberagaman produk adalah sebesar $-0,416$, nilai thitung variabel persepsi harga sebesar $-0,071$, dan nilai thitung variabel promosi penjualan sebesar 3.982. Dengan demikian dapat disimpulkan bahwa variabe Promosi $_{1}$ Penjualan mempunyai pengaruh yang dominan terhadap Kepuasan Konsumen Hypermarket Supermall Pakuwon di Surabaya dibandingkan dengan variabel yang lain. 


\section{Saran}

Dari hasil penelitian ini dapat disampaikan saran sebagai berikut:

1. Bagi peneliti selanjutnya disarankan untuk melakukan penelitian diluar variabel bebas yang sudah digunakan dalam penelitian ini, misalnya saluran distribusi, Promosi dan lain - lain, ataupun mengkombinasikan salah satu varabel dalam penenlitian ini dengan variabel lain di luar variabel penelitian ini. Mengingat terdapat pengaruh yang sangat besar dari variabel lain.

2. Promosi penjualan dalam penelitian ini berpengaruh signifikan terhadap kepuasan konsumen. Oleh karena itu disarankan agar perusahaan berupaya meningkatkan promosi penjualan dan menjaga promosi penjualan supaya tetap konsisten dilakukan sehingga kepuasan konsumen tetap terjaga., tetapi tidak mengabaikan faktor lain.

\section{DAFTAR PUSTAKA}

Alma, B. 2002. Manajemen Pemasaran dan Pemasaran Jasa. Alfabeta. Bandung. Arikunto, Suharsimi. 1998. Dasar-Dasar Metodelogi Penelitian.,Gelar Pustaka Mandiri, Jakarta

Gerson, R.F. 2004. Mengukur Kepuasan Pelanggan. Cetakan 3. PPM. Jakarta. Iksan, Leonid, Yohanes Sondang Kunto (2013), Analisa Pengaruh Kualitas Layanan terhadap Kepuasan Konsumen pada Layanan Drive Thru

McDonald's Basuki Rahmat di Surabaya, Jurnal Manajemen Pemasaran Vol. 1, No. 1, (2013) 1-12.

Kotler, P. 2002. Manajemen Pemasaran. Edisi Bahasa Indonesia. Jilid 1. Prenhall Indonesia. Jakarta.

Kotler, Philip, dan Kevin lane Keller. 2009. Manajemen pemasaran Jilid 1 , edisi Ketiga belas, Terjemahan Bob Sabran, MM. Jakarta: Penerbit Eralngga.

Kotler, Philip, dan Kevin lane Keller. 2009. Manajemen pemasaran Jilid 2 , edisi Ketiga belas, Terjemahan Bob Sabran, MM. Jakarta: Penerbit Eralngga. 
Lovelock, C.H. dan L.K. Wright. 2005. Pemasaran Jasa. Edisi Bahasa Indonesia.

Masri Singarimbun dan Sofian 1989 Metode dan Proses Penelitian, LP3ES.Jakarta

Nasir, Mohammad 1999. Metode Penelitian. Ghalia Indonesia, Jakarta

Rangkuti, F. 1997. Riset Pemasaran. Gramedia Pustaka Utama. Jakarta

Rangkuti, F. 2006. Measuring Customer Satisfaction : Teknik Mengukur danStrategi Meningkatkan Kepuasan Pelanggan Plus Analisis Kasus PLNJP.

Sugiyono. 2004. Metode Penelitian Bisnis. Alfabeta, CV. Bandung

Sumarwan, U. 2003. Perilaku Konsumen : Teori dan Penerapannya DalamPemasaran. Ghalia Indonesia. Jakarta.

Sugiyono, 2005, Metode Penelitian Administrasi, CV Alfabeta, Bandung

Tjiptono, F. 2001. Manajemen Jasa. Andi. Yogyakarta. 